\title{
МОВОЗНАВСТВО. NITEPATУРOЗНАВCTBO
}

УДК 81'255.2:629.7(045)

DOI https://doi.org/10.24919/2308-4863/38-2-14

Галина СНЧЕВА,

orcid.org/0000-0003-2002-6761

кандидат філологічних наук, доцент, дочент кафедри англійської філології і перекладу

Начіонального авіачійного університету

(Київ, Україна) halyna.yencheva@npp.nau.edu.ua

Людмила ГАЛІй,
огсіd.org/0000-0003-0468-5978
кандидат філологічних наук,
дочент кафедри англійської філологї̈ і перекладу
Національного авіачійного університету
(Київ, Україна) liudmyla.halii@прр.паи.еdи.иа

Слсна ТОМАШЕВСБКА,

orcid.org/0000-0002-2046-8976

студентка II курсу магістратури кафедри англійської філологї і перекладу

Національного авіаційного університету

(Київ, Україна)Toma1235@ukr.net

\section{ФРАЗЕОЛОГІЧНІ ОДИНИЦІ 3 ТОПОНІМІЧНИМ КОМПОНЕНТОМ: ЛІНГВО-КУЛЬТУРОЛОГІЧНИЙ ТА ПЕРЕКЛАДОЗНАВЧИЙ АСПЕКТ}

Стаття присвячена дослідженню фразеологічних одиниць із топонімічним компонентом в англійській та украйнській мовах у лінгвокультурологічному та перекладознавчому аспектах. Здійснено спробу теоретично обтрунтувати особливості англійських фразеологізмів, щуо містять топонімічний компонент, та практично проаналізувати особливості їхнього перекладу українською мовою. У статті окреслено різні підходи щзодо розуміння лінгвокультурно обумовлених фразеологізмів, зазначається, щчо лінгвокультурно обумовлені фразеологізми включають фразеологічні одиниці, щуо мають позамовне підгрунтя та є джерелом культурної інформації про краӥну носіїв мови.

До складу лінгвокультурно обумовлених фразеологізмів входять, поряд з іншими, $і$ ФО із компонентомтопонімом. Автори зауважують, що топонімічний компонент у складі ФО є важливим об' єктом аналізу, оскільки вивчення таких компонентів допомагає зрозуміти національний менталітет, моральні принципи народу, тип його світосприйняття та дає можливість більше дізнатися про географію тієї чи тієї країни. У статті зазначено особливості функиіонування фразеологічних одиниць, описано механізми їхнього утворення, досліджено структуру фразеологічних одиниць із топонімічним компонентом, проаналізовано способи перекладу фразеологічних одиниць із топонімічним компонентом украӥнською мовою. Акиентовано увагу на класифікації еквівалентів фразеологізмів п'яти ступенів: повні, часткові, відносні еквіваленти, фразеологічні аналоги, без еквівалентні фразеологізми. Автори доходять висновку, щзо специфіка культурного топонімічного компонента в аналізованих фразеологічних одиницях обумовлює той факт, щүо нефразеологічні способи перекладу переважають над фразеологічними.

3 'ясовано, що труднощі пошуку еквівалента при перекладі англійських фразеологізмів з топонімічним компонентом украӥнською мовою обумовлені національними особливостями концептуалізації топонімів в українській та англійській мовах, щз свідчить про відмінності у функціонуванні національної мовної свідомості.

Ключові слова: фразеологічна одиниця з топонімічним компонентом, культурологічний аспект, перекладознавчий аспект, перекладацький еквівалент, способи перекладу. 


\section{Halyna YENCHEVA, \\ orcid.org/0000-0003-2002-6761 \\ Candidate of Philological Sciences, Associate Professor, Associate Professor at the Department of English Philology and Translation \\ National Aviation University \\ (Kyiv, Ukraine) halyna.yencheva@npp.nau.edu.ua}

Liudmyla HALII,
orcid.org/0000-0003-0468-5978
Candidate of Philological Sciences,
Associate Professor at the Department of English Philology and Translation
National Aviation University
(Kyiv, Ukraine) liudmyla.halii@npp.nau.edu.ua

Yeliena TOMASHEVSKA,

Master's Student

National Aviation University

(Kyiv,Ukraine)Toma1235@ukr.net

\section{PHRASEOLOGICAL UNITS WITH TOPONYMIC COMPONENT: LINGUOCULTURAL AND TRANSLATION ASPECTS}

The article studies the phraseological units with toponymic component in linguocultural and translation aspects in English and Ukrainian. It provides an attempt give theoretical grounding for the specifics of English phraseological units that contain toponymic component and to give practical analysis of their translation into Ukrainian. The article outlines different ways of defining and interpreting linguoculturally dependent phrases and states that the latter include phraseological units of extra-lingual origin and at the same time are the source of information on the culture of native-speakers. Linguoculturally dependent phrases include, alongside all the others, phraseological units with toponymic component. The authors note that studying the above-mentioned components enhances better understanding of national mentality, national moral grounds, type of worldview and provides an opportunity to learn more on the geography of specific country. The article also states special features of phraseological units functioning, describes the way they are formed, studies the structure of phraseological units with toponymic component, analyses the ways of their translation into Ukrainian.

Special attention is paid to classifying phraseological equivalents into five degrees: complete, partial, relative equivalents, phrasal analogues, non-equivalent phrases. The authors conclude that the specifics of cultural toponymic component in the analyzed structures defines the fact that non-phraseological ways of translation dominate the phraseological ones.

It has been found out that difficulty to find the correct equivalent while translating English phrases with toponymic component into Ukrainian is due to national peculiarities of conceptualizing toponyms in English and Ukrainian which proves the difference in national language consciousness.

Key words: phraseological unit with toponymic component, linguocultural aspect, translation aspect, translation equivalent, ways of translation.

Постановка проблеми. В англійській лінгвістиці проблема функціонування лінгвокультурно обумовлених фразеологізмів залишається гострою та суперечливою у світлі сучасних лінгвістичних досліджень, зокрема тому, що не існує чітких критеріїв розподілу між різними класами таких ФО. Існують різні підходи в розумінні обсягу лінгвокультурно обумовлених фразеологізмів. Деякі фразеологи (I. Авер'янова, Т. Павлова та ін.) (Аверьянова И. Е., 2006; Павлова Т. Н., 2011) дотримуються тут широкого підходу - вважають національно специфічними широке коло фразеологічних явищ, зокрема визнають лінгвокультурно обумовленими всі ФО. Інші (О. Колесникова, О. Мотріченко та ін.) (Колесникова О., 2007;
Мотріченко О., 2017) займають прямо протилежну позицію - відносять до числа національно зазначених тільки ті фразеологізми, до складу яких входять найменування реалій. I, нарешті, $\epsilon$ ще одна думка: фразеологи, які працюють в ключі компаративістики (3. Корнєва, О. Кунін та ін.) (Корнєва 3., 2018; Кунин А.), - кваліфікують в якості лінгвокультурно обумовлених фразеологізмів ті, що втілюють собою міжмовні відмінності. Ми вважаємо, що термін «лінгвокультурно обумовлені фразеологізми» $є$ загальною назвою для таких типів ФО, i, слідом за І. Авер'яновою, вважаємо, що лінгвокультурно обумовлені фразеологізми включають ФО, що «мають позамовне підгрунтя та $є$ джерелом культурної інформації 
про країну носіїв мови» (Аверьянова И.Е. : 2006). А інші терміни є видами стосовно них.

До складу лінгвокультурно обумовлених фразеологізмів входять, поряд з іншими, і ФО із компонентом-топонімом. Топонім - це мовна одиниця, що має вказівку на географічні об'єкти як цілісні та відносно стійкі утворення Землі природного чи антропогенного походження, які існують або існували в минулому та характеризуються конкретним розташуванням. Топонім - це факт мови, який фіксований географічно і є джерелом та матеріалом для історії нації, іiі мови, тому він включає значну культурну складову (Ермолович Д.И., 2013: с. 17). Топоніми можуть переходити від категорії «прозорих» (зі значенням та мотивацією, зрозумілими для звичайного мешканця), до «непрозорих» (ті географічні назви, які сьогодні не мають чіткого значення, втратили його або є незрозумілими, але використовуються як назви географічних об’ єктів) (Жучкевич В. А., 1980: с. 102).

Топонімічний компонент у складі ФО є важливим та цікавим об'єктом аналізу. Вивчення таких компонентів допомагає зрозуміти національний менталітет, моральні принципи народу, тип його світосприйняття та дає можливість більше дізнатися про географію тієї чи тієї країни. Широке включення топонімічного компоненту до складу фразеологізмів обумовлено тим, що топонім, за словами Р. Гончарука, «має найвищий ступінь синтетичності (концентрації), тобто містить у своїй об'єктивній структурі різноманітну інформацію, лінгвістичну та екстралінгвістичну» (Гончарук Р. А., 2011: с. 90). Лінгвокультурний характер топонімічного елементу впливає на можливість розуміння фразеологізму та його перекладу (Szerszunowicz J., 2008).

Аналіз останніх досліджень i публікацій. Англійські фразеологізми вивчали В. Бобков, Р. Гіббс, Р. Глязер, О. Кунін, Л. Терлецька та ін. Фразеологічний фонд української мови аналізувався у дослідженнях таких авторів, як: Я. Баран, В. Білоноженко, О. Важеніна, П. Срченко, Л. Мойсеєнко, О. Селіванова, Н. Сіденко, В. Южченко та ін. Предметом зіставного аналізу фразеологічні одиниці були у працях таких дослідників, як О. Арсентьєва, Р. Глязер, Т. Ніколаєва, О. Селіванова, Е. Солодухо та ін. Лінгвокультурологічний аспект лексикології та фразеології досліджували I. Аверьянова, М. Бондар, А. Бронська, В. Воробйов, М. Гутковська, В. Котович, В. Маслова, О. Мотріченко, Т. Ніколаєва, Т. Павлова, О. Селіванова, Г. Томахін, О. Тупиця Н. Фененко иа ін. $\Phi O$ із компонентом-топонімом досліджували такі вчені, як Г. Ваніна, Ю. Демешевська, Р. Гон- чарук, Г. Сударь та ін. в тому числі в англійській мові - О. Алексєєва, 3. Корнєва та ін. На особливостях перекладу фразеологізмів зосереджували увагу С. Влахов, Р. Зорівчак, В. Іванов, О. Кунін, О. Селіванова, О. Тупиця, С. Флорін та ін.

Водночас проблема аналізу фразеологічних одиниць із топонімічним компонентом в англійській та українській мовах у лінгвокультурологічному та перекладознавчому аспектах недостатньо досліджена у вітчизняному мовознавстві та перекладознавстві, що обумовлює актуальність обраної теми дослідження.

Мета і завдання статті - теоретично обгрунтувати особливості англійських фразеологізмів, що містять топонімічний компонент та практично проаналізувати особливості їх перекладу українською мовою.

Виклад основного матеріалу. Топоніми називаються «індивідуальними», якщо в них міститься інформація для всієї мовної групи, тобто вона кодифікується на рівні системної мови, наприклад, топонім London ыз такими ознаками, як " $a$ big city, the capital of Great Britain". Решта топонімів, які лише потенційно здатні отримати мовний статус зі значним індивідуалізуючим значенням, називаються «груповими». На цій підставі українська дослідниця 3. Корнєва виділяє дві групи ФО iз топонімічним компонентом: ФО, що включають індивідуальні топоніми (наприклад, Bess o'Bedlam; Wellington boots), та ФО, що включають групові топоніми (наприклад, from China to Peru, from John o'Groats to Land's End) (Корнєва 3., 2018: с. 323). При цьому, як зауважують Г. Ваніна та Ю. Демшевська, топонім у фразеологізмі може бути не завжди справжнім, він може мати міфологічне, казкове походження або бути взагалі вигаданим (Ваніна Г., Демшевська Ю., 2013). Оскільки аналіз ФО з топонімічним компонентом втілює два аспекти: конотативний та денотативний, то дуже важливим $€$ вивчення походження топоніма та його еволюції в складі фразеологізму (Сударь Г. С., 2004: с. 44).

3 погляду лінгвокультурології ФО із топонімами виконують такі функції (Алексєєва О., 2016: с. 6): 1) відбивають національну культуру розчленовано, одиницями свого складу, деякі з них належать до числа зворотів, не маючих еквівалентів; 2) відбивають національну культуру комплексно, своїм фразеологічним значенням; 3) відбивають національну культуру своїми прототипами, оскільки спочатку вільні словосполучення описують певні звичаї, традиції, особливості побуту і культури та історичні події. Отже, фразеологізми iз топонімічним компонентом допомагають розкрити багатовікову історію Великобританії та 
інших англійськомовних країн, розповідаючи про відомі і невідомі населені пункти цих країн та спосіб життя англійськомовного народу. Тому важливо дослідити аспекти їх перекладу.

У перекладознавстві існує багато підходів до перекладу, причому в останній час підвищений інтерес займає метод структурно-семантичного моделювання, що дозволяє зіставити еквівалентні переклади фразеологічних і ідіоматичних фондів різних мов на основі аналізу конкретних семантичних полів. О. Солодухо (Солодухо Э., 1989: с. 22) пропонує власну класифікацію еквівалентних i нееквівалентних відповідностей і виділяє три види еквівалентів: 1) тотожні еквіваленти; 2) прямі еквіваленти; 3) синонімічні еквіваленти. Крім того, дослідник виділяє фразеологічний аналог образну фразеологічну одиницю в мові-реципієнті, за змістом аналогічну фразеологічній одиниці в мові-джерелі, але засновану на іншому образі.

Найбільш переконливою класифікацією еквівалентів у різних мовах $є$ система п'яти ступенів (повні, часткові, відносні еквіваленти, фразеологічні аналоги, безеквівалентні фразеологізми) О. О. Селіванової (Селіванова О., 2012: с. 27).

У результаті проведеного дослідження було виявлено фразеологічні та нефразеологічні види перекладу ФО із топонімами.

I. Переклад повним еквівалентом (6 од., 4,7\%), зокрема: at the Greek calends (aбо kalends) буквально: «до грецьких календ» у значенні «дуже довго», «ніколи»; (БАУФС: А-991) $\rightarrow$ до греиьких календ; City of the Seven Hills буквально: «місто на семи пагорбах» у значенні «Рим» (БАУФС: С-672) $\rightarrow$ місто на семи пагорбах.

Повні еквіваленти мають однакову структуру, подібну основу, переносне значення і функціонально-стилістичне забарвлення. Як бачимо 3 наведених прикладів, повним компонентом переважно перекладаються фразеологізми, що містять топоніми із класичної історії, містяться у багатьох прецедентних текстах i, отже, є відомими для носіїв як англійської, так і української культур.

II. Переклад иастковим еквівалентом (3 од., 2,3\%), зокрема: Land of Nod буквально: «земля Нод», у значенні «царство сну» (БАУФС: L-53) $\rightarrow$ сонне иарство; London particular буквально: «Лондонська особливість» у значенні «лондонський туман»; (БАУФС : L-1088) $\rightarrow$ Лондонський туман; Roman реасе буквально: «римський мир» у значенні «мир між переможеними країнами, що ввійшли до складу Римської Імперії»; (БАУФС) $\rightarrow$ римська угода.

Часткові еквіваленти мають таке ж значення $\mathrm{i}$ внутрішню форму і відрізняються або за структу- рою, набору синонімічних компонентів, сполучуваності, кількості компонентів, ступеня вживання, або за іншою ознакою, що випливає з граматичної структури мови перекладу. Так, ми бачимо, що у наведених прикладах використана конкретизація particular $\rightarrow$ туман чи, навпаки, генералізація: peace $\rightarrow$ угода, але в цілому дібрані українські ФО еквівалентні за структурою та семантикою.

III. Переклад відносним еквівалентом (12 од., 9,4\%), зокрема: Arabian bird буквально: «арабський птах», у значенні «фенікс»; у переносному значенні «унікум»; (БАУФС: А-524) $\rightarrow$ пташине молоко; Arabian nights буквально: «арабські ночі» у значенні «казки «Тисяча і одна ніч»», «арабські казки»; у переносному значенні, «неправдоподібне оповідання»; (БАУФС: А-525) $\rightarrow$ казка про білого бичка; ark rested on Mt. Ararat буквально: ковчег на горі Арарат у значенні «Ноєв ковчег» у переносному значенні «тісне приміщення»; (БАУФС: А-539) $\rightarrow$ ноєв ковчег; Chinese tumbler буквально: «китайський акробат», у значенні «іван-покиван» (БАУФС: С-619) $\rightarrow$ іван-покиван; (БАУФС: W-522) $\rightarrow$ між який народ попадеш, того й шапку надівай.

Відносні еквіваленти при тому ж значенні частково замінюють образність, але залишаються зіставними. Наприклад, when at Rome, do as the Romans do $\rightarrow$ між який народ попадеш, того й шапку надівай. У цих ФО однакова семантика, а слово «народ» в українському фразеологізмі актуалізує таку ж саме образність, що і в англійському, хоч назва народу і не уточнюється. У ФО Scotch boot $\rightarrow$ іспанський чобіт змінено топонім та вид взуття, але ці ФО визивають однакові асоціації.

IV. Переклад фразеологічним аналогом (24 од., 18,8\%), зокрема: Lombard Street to a China orange буквально: «Ломбард-стріт до китайських апельсинів» у значенні «непорівнювані речі»; (БАУФС: L-1087) $\rightarrow$ як свиня на коня; man of Gotham буквально: «людина з Готхема», у значенні «обмежена, недалека людина»; (БАУФС: М-769) $\rightarrow$ розумний, як Беркові штани; Philadelphia lawyer буквально: «філадельфійський адвокат», у значенні «людина 3 гострим розумом; пройдисвіт»; (БАУФС: Р-357) $\rightarrow$ великий дурисвіт (шахpaü); Punica Tides буквально: «пунічна вірність», «карфагенська вірність» у значенні «підступність, віроломність»; (БАУФС) $\rightarrow$ троянський кінь; put Yorkshire over one буквально: «поставити Йоркшир зверху», у значенні «обдурити когось» (БАУФС: Р-1878) $\rightarrow$ Роззув молодия із чобіт в nостоли; Scotch broth буквально: «шотландський бульон» у значенні «перловий суп»; (БАУФС) $\rightarrow$ cyn зі шрапнеллю; Scotch cousin буквально: 
«шотландський кузен», у значенні «далекій родич»; (БАУФС) $\rightarrow$ сьома вода на киселі; Scotch verdict буквально: «шотландський вердикт», у значенні «виправдний вирок» (БАУФС: S-195) $\rightarrow$ виправдний вирок; Serbonian bog; буквально: «Сербонійське болото», у значенні «безвихідне становище» (БАУФС: S-513) $\rightarrow$ i mym боляче, $i$ там гаряче; tell it not in Bond Street буквально: «не кажіть цього на Бонд-стріт», у значенні «не кажіть про це комусь іншому; не тіште наших ворогів цією (неприємною для нас) звісткою»; (БАУФС: $\mathrm{T}-301) \rightarrow$ не виносити сміття з хати; tell it not on St. James's pavement буквально: «не кажіть цього на тротуарі Сент-Джеймс», у значенні «не кажіть про це комусь іншому; не тіште наших ворогів цією (неприємною для нас) звісткою»; (БАУФС: Т-301) $\rightarrow$ не виносити сміття з хати; tо assist in the French sense буквально: «допомагати по-французьки», у значенні «бути присутнім при виконанні справи, але не допомагати» (БАУФС) $\rightarrow$ надавати моральну підтримку.

Фразеологічні аналоги мають різну образність або структуру, але загальне значення і стилістику. Наприклад, ФО wise man of Gotham $\rightarrow$ розумний, як Беркові штани обидва мають іронічну конотацію і розуміти їх обидва треба навпаки. Звернемо увагу та те, що переклад Punica Tides $\rightarrow$ троянський кінь ми віднесли до фразеологічних аналогів, в той час, як переклад Greek gift $\rightarrow$ троянський кінь - до відносних еквівалентів. Переклад доцільний в обох випадках, бо має однакову семантику і дещо схожу образність, проте саме Greek gift має алюзію та Троянську війну, тоді як інша ФО відноситься до інших історичних подій.

V. Нееквівалентний переклад (83 одиниці, $64,8 \%$ ), у тому числі:

5.1. Лексичні трансформацї, зокрема, формальні та лексико-семантичні (56 од., 43,8\%), зокрема:

5.1.1. Калька (10 од., 12,8\%), зокрема: Black Belt буквально: «чорна зона» у значенні «південні райони США, в яких переважає негритянське населення» (БАУФС: В-2097) $\rightarrow$ Чорна зона; City of the Angels буквально: «місто ангелів» у значенні «Лос-Анжелес» (БАУФС: С-670) $\rightarrow$ місто ангелів, Lake School буквально: «озерна школа», у значенні «школа поетів-романтиків XIX ст.»; (БАУФС: L-38) $\rightarrow$ озерна школа; London season буквально: «Лондонський сезон» у значенні «час пожвавлення розваг лондонської знаті»; (БАУФС : $\mathrm{L}-1089) \rightarrow$ Лондонський сезон; prince of Wales' feather буквально: «перо принца Уельського», у значенні «плюмаж страусових пір'їв» (БАУФС: P-1032) $\rightarrow$ перо принцуа Уельського; Provisions of Oxford буквально: «Оксфордські провізії», у значенні «конституція, вироблена в Оксфорді у 1258 р.» (БАУФС: Р-1116) $\rightarrow$ Оксфордські провiзiї; White House буквально: «білий дім», у значенні «резиденція Президента США»; (БАУФС: $\mathrm{W}-870) \rightarrow$ білий дім.

5.1.2. Транскрибування та транслітераџія (2 од., 1,6\%), зокрема: Lombard Street буквально: «Ломбард-стріт» у значенні «фінансовий центр Англії»; (БАУФС : L-1086) $\rightarrow$ Ломбард-Cmpim; Big Ben буквально: «Великий Бен» у значенні «годинник на будинку англійського парламенту» (БАУФС: Б-1932) $\rightarrow$ Біг Бен;

5.1.3. Модуляція (44 од., 34,4\%). Модуляцію використано у таких випадках, коли в оригінальній ФО топонім названий непрямо, а при перекладі через логічний та семантичний розвиток відновлюється назва топоніма, що малася на увазі. Зокрема: Badger State буквально: «Штат борсуків» у значенні «штат Вісконсін» (БАУФС: В-56) $\rightarrow$ uтат Вісконсін; Bear State буквально: «медвежий штат» у значенні «штат Арканзас» (БАУФС: B-335) $\rightarrow$ umam Арканзас; City of Brotherly Love буквально: «місто братерської любові» у значенні «місто Філадельфія» (БАУФС: С-666) $\rightarrow$ місто Філадельфія; City of the Golden Gate буквально: «місто золотих воріт» у значенні «місто Сан-Франциско» (БАУФС: С-671) $\rightarrow$ місто СанФраничиско; Father of Rivers (npo Miccicini) буквально: «батько річок» у значенні «Міссісіпі» (БАУФС: F-285) $\rightarrow$ річка Miccicini; Father of Waters буквально: «батько вод» у значенні «Ніл» (БАУФС: F-285) $\rightarrow$ Ніл; Forest City амер. «містоліс» буквально: «місто-ліс» у значенні «Клівленд» (БАУФС: F-1044) $\rightarrow$ Клівленд; garden of the West буквально: «сад Заходу» у значенні «штат Ілінойс та штат Канзас» (БАУФС: G -70) $\rightarrow$ итат Іллінойс ma umam Канзас; Garden State буквально: «штат садів» у значенні «штат Канзас» (БАУФС: G-72) $\rightarrow$ umam Канзас; Lake Slate буквально: «озерний штат», у значенні «штат Мічиган»; (БАУФС: L-39) $\rightarrow$ umam Мічиган; playground of Europe, буквально: «спортивний сайданчик Європи», у значенні «Швейцарія» (БАУФС: Р-617) $\rightarrow$ Швейцарія; Queen City of the Lakes буквально: «королівське місто озер», у переносному значенні «перлина озер», у значенні «місто Буффало в штаті Нью-Йорк» (БАУФС: Q-12) $\rightarrow$ місто Буффало; Squatter State буквально: «штат поселенців» у значенні «штат Канзас» (БАУФС: G-72) $\rightarrow$ umam Kaнзас; Sucker State буквально: «штат смоктунів» у значенні «штат Іллінойс» (БАУФС: Р-928) $\rightarrow$ uтат Іллінойс; Sunflower State буквально: «штат соняшників» у значенні «штат Канзас» (БАУФС: G 72) $\rightarrow$ umam Канзас; Wolverine Slate бук- 
вально: «штат росомах», у значенні «штат Мічиган»; (БАУФС: W-1215) $\rightarrow$ штат Мічиган.

5.2. Граматичні трансформаиії, представлені синтаксичною заміною (9 од., 7\%). Синтаксична заміна припускає зміну граматичних конструкцій. Зокрема, фразеологім перекладається словом (у термінології О. Куніна - лексемний переклад), зокрема: Balaclava helmet буквально: China bark буквально: «перуанська кора», у значенні «хіна» (БАУФС: С-617) $\rightarrow$ хіна; Peruvian bark буквально: «перуанська кора», у значенні «хіна» (БАУФС: Р-343) $\rightarrow$ хіна; Russian leather; буквально: «російська шкіра», у значенні «юхта» (БАУФС: R-937) $\rightarrow$ юxта; Scotch mist буквально: «шотландський туман», у жартівливому значенні «дрібний дощ»; $($ БАУФС) $\rightarrow$ мрячка; Venetian blind у значенні жалюзі; (БАУФС: V-24) $\rightarrow$ жалюзі;

5.3. Лексико-граматичні трансформації, представлені иілісним перетворенням та описовим перекладом (18 од., 14,1\%), зокрема: $A B C$ у значенні «дешевий ресторан в Лондоні (скор. Aerated Bread Company's Shop)»; (БАУФС: А-8) $\rightarrow$ дешевий ресторан в Лондоні; Arkansas toothpick буквально: «арканзаська зубочистка» у значенні «довгий мисливський ніж»; (БАУФС: А-538) $\rightarrow$ довгий мисливський ніж; Bad Lands буквально: «погані землі» у значенні «неродючі області на заході США» (БАУФС: В-65) $\rightarrow$ неродючі області на заході США; Chinese collar буквально: «китайський комір», у значенні «стоячій комір» (БАУФС: C-618) $\rightarrow$ стоячий комір; garden of England буквально: «сад Англії» у значенні «південні райони Англії» (БАУФС: G-69) $\rightarrow$ південні райони Англії; Old Lady in Threadneedle Street,; буквально: «стара леді з Треднілд-стріт», у значенні «англійський банк»; (БАУФС: О-301) $\rightarrow$ англійський банк; Scotch hands буквально: «шотландські руки», у значенні «двійка лопаток для розрізання і накладання масла» (БАУФС: S-191) $\rightarrow$ двійка лопаток для розрізання і накладання масла; Venetian pearl буквально: «венеціанська перлина», у значенні «штучна перлина»; (БАУФС: V-26) $\rightarrow$ штучна перлина; Welsh rabbit буквально: «уельський кролик», у значенні «грінки з сиром»; (БАУФС: W-37) $\rightarrow$ грінки з сиром. Здійснено квантитативний аналіз для визначення частотності різних способів перекладу ФО із топонімами.

Висновки. Отже, можемо зробити висновок, що специфіка культурного топонімічного компонента в аналізованих ФО обумовлює той факт, що нефразеологічні способи перекладу переважають над фразеологічними. Найчастотнішим виявився саме нефразеологічний спосіб перекладу, зокрема, така лексико-семантична трансформація, як модуляція $(34,4 \%)$. Частково це обумовлено впливом американської культури на англійський фразеологічний фонд, багато фразеологізмів на позначення американських штатів та міст надано алегорично. Представнику українськомовної культури без належних фонових знань, наприклад, важко здогадатися, що означає «Штат Мерлузи», тому перекладачеві доводиться відновлювати у перекладі основне значення «штат Міссісіпі». Звичайно, наш аналіз здійснювався на лексикографічних джерелах, якщо би йшлося, наприклад, про переклад художньої літератури, то можливі варіанти - наприклад, у першому випадку, коли топонім зустрічається у тексті, надати перекладацький коментар, а надалі перекладати цю ФО калькою.

Середню частотність продемонстрував такий спосіб перекладу, як переклад фразеологічним аналогом $(18,8 \%)$. Цей спосіб перекладу виявився найчастішим 3 усіх фразеологічних способів відтворення фразеологізмів із топонімічним компонентом. Такий нефразеологічний спосіб, як цілісне перетворення та описовий переклад $(14,1 \%)$, використовувався із середньою частотністю. Калька $(12,8 \%)$ використовувалася у тих випадках, коли значення перекладеного таким чином ФО з високим ступенем вірогідності має бути відомим представникам українськомовної культури. Переклад відносним еквівалентом здійснювався у $9,7 \%$ випадків.

Серед нечастотних способів перекладу можна назвати синтаксичну заміну, коли фразеологізм відтворювався однією лексемою (7\%). Переклад повним еквівалентом склав лише 4,7\%, і переважно таким чином перекладалися фразеологізми iз античними топонімами, які наявні і в англійській, і в українській мовах. Найрідше зустрічалися такі способи перекладу як переклад частковим еквівалентом $(2,4 \%)$ та транскрибування i транслітерація $(1,6 \%)$.

Труднощі пошуку еквівалента при перекладі англійських фразеологізмів 3 топонімічним компонентом українською мовою обумовлені національними особливостями концептуалізації топонімів в українській та англійській мовах, що свідчить про відмінності у функціонуванні національної мовної свідомості.

\section{СПИСОК ВИКОРИСТАНИХ ДЖЕРЕЛ}

1. Аверьянова И.Е. Русская культурно-маркированная лексика в англоязычных произведениях о России и Великой Октябрьской Социалистической революции . Дис.. канд. филол. наук. Москва., 2006. 133 с. 
2. Алексєєва О. Деякі аспекти дослідження фразеологізмів, що містять топоніми, у курсі країнознавства Великобританії. Записки з романо-германської філологї̈. 2016. Вип. 2 (37). С. 3-10.

3. Бельмаз Я. Етимологічні особливості топонімії Великої Британії. URL: http://77.121.11.9/bitstream/PoltNTU/ B4_16.pdf

4. Ваніна Г., Демшевська Ю. Особливості фразеологічного фонду іспанської мови з топонімічним компонентом. Нова філологія. 2013. № 57. С. 109 - 111.

5. Гончарук Р.А. Теоретико-методичні засади утворення фразеологічних одиниць 3 топонімічним компонентом (на матеріалі німецької мови). URL: http://www.irbis-nbuv.gov.ua/cgi-bin/irbis_nbuv/cgiirbis_64.exe?C21COM=2\&I21D $\mathrm{BN}=\mathrm{UJRN} \& \mathrm{P} 21 \mathrm{DBN}=\mathrm{UJRN} \& \mathrm{IMAGE}$ FILE DOWNLOAD=1\&Image file name=PDF/Nznuoaf_2013 37 31.pdf

6. Ермолович Д.И. Имена собственные: теория и практика межъязыковой передачи. Москва : Р. Валент, 2013. 416 с.

7. Жучкевич В.А. Общая топонимика. Минск : Высшая школа, 1980. 288 с.

8. Колесникова О. Фразеологизмы со значением эмоционального состояния и их роль в межкультурной коммуникации. Ученые записки Таврического национального университета им. В. И. Вернадского Серия «Филология». 2007 Том 20 (59). C. 319-324.

9. Корнєва 3. Ономастичний компонент у складі англійських фразеологічних одиниць та його відтворення в українському перекладі. Молодий вчений. 2018. № 11 (63). С. 321-326.

10. Кунин А.В. О переводе английских фразеологизмов. URL: http:// zhurnal.lib.ru/w/wagapow_a_s/transl/bookkunin.shtml.

11. Мороз О. Семантика та структура номінативних фразеологічних одиниць з компонентом «власне ім'я». URL: http://nbuv.gov.ua/j-pdf/Nchnpu_10_2011_8_77.pdf.

12. Мотріченко О. Культурно-маркована лексика сучасної мови гінді (типологічний аспект). Індія: давнина $i$ сучасність. 2017. Вип. II. С. $193-199$.

13. Музя Е.М. Принципы классифицирования топонимов. Вісник Запорізького державного університету. Філологічні науки. 2002. № 1. С. 95-98.

14. Павлова Т.Н. Прагматический потенциал культурно-маркированной лексики в публичной речи. Нова філологія. 2011. № 46. С. 174-176.

15. Селіванова О. Проблема трансформацій в перекладознавстві. Вісник Черкаського університету. Серія філологічні науки. 2012. Вип. 3. С. 33-40.

16. Серебренников Б.А. О методах изучения топонимических названий. Вопросы языкознания. 1959. № 6. С. 36-51.

17. Солодухо Э. Теория фразеологического сближения. Казань : КГУ, 1989. 296 с.

18. Сударь Г.С. Топоним в составе испанского фразеологизма. Актуальные проблемы современной иберороманистики. Москва : МГУ. Факультет иностранных языков, 2004. С. 44.

19. Elliott K. A Survey of the History of English Place-Names. URL: heraldry.sca.org/names/engplnam.html.

20. Mills A.D. A Dictionary of English Placenames. New York : Oxford University Press, 1991.

21. Szerszunowicz J. Some remarks on English idioms containing first names and their Polish equivalents. Proceedings. Nation and Language: Modern Aspects of Sociolinguistic Development. 2nd International Conference. Kaunas University of Technology, Panevėžys Institute. Lithuania, 2008.

\section{REFERENCES}

1. Averianova, Y. E. (2006). Russkaia kulturno-markyrovannaia leksyka v anhloiazuchnukh proyzvedenyiakh o Rossyy y Velykoi Oktiabrskoi Sotsyalystycheskoi revoliutsyy. [Russian culturally-marked vocabulary in English-language works about Russia and the Great October Socialist Revolution] avtoreferat dyssertatsii ... kandydata filolohichnykh nauk : 10.02.04. Moscow, 133 p. [in Russian].

2. Aleksieieva O. (2016). Deiaki aspekty doslidzhennia frazeolohizmiv, shcho mistiat toponimy, u kursi krainoznavstva Velykobrytanii. [Some aspects of the study of phraseology containing toponyms in the course of British studies]. Zapysky z romano-hermanskoi filolohii, Vol. 2 (37). pp. 3-10 [in Ukrainian].

3. Belmaz Ya. (2013). Etymolohichni osoblyvosti toponimii Velykoi Brytanii. [Etymological features of toponymy of Great Britain]. URL: http://77.121.11.9/bitstream/PoltNTU/B4_16.pdf [in Ukrainian].

4. Vanina H., Demshevska Yu. (2013). Osoblyvosti frazeolohichnoho fondu ispanskoi movy z toponimichnym komponentom. [Features of the phraseological fund of the Spanish language with a toponymic component]. Nova filolohiia, № 57. p.p. 109-111 [in Ukrainian].

5. Honcharuk R. A. (2011). Teoretyko-metodychni zasady utvorennia frazeolohichnykh odynyts z toponimichnym komponentom (na materiali nimetskoi movy).Теоретико-методичні засади утворення фразеологічних одиниць 3 топонімічним компонентом (на матеріалі німецької мови). [Theoretical and methodological principles of formation of phraseological units with a toponymic component (on the material of the German language] URL: http://www.irbisnbuv.gov.ua/cgibin/irbis_nbuv/cgiirbis_64.exe?C21COM=2\&I21DBN=UJRN\&P21DBN=UJRN\&IMAGE FILE DOWNLOAD=1\&Image_file_name=PDF/Nznuoaf_2013_37_31.pdf [in Ukrainian].

6. Ermolovich D. I. (2013). Imena sobstvennyie: teoriya i praktika mezh'yazyikovoy peredachi. [Proper names: theory and practice of interlanguage transmission ]. Moscow: R. Valent, $416 \mathrm{p}$. [in Russian].

7. Zhuchkevich V. A. (1980). Obschaya toponimika. [General toponymy]. Minsk : Vyisshaya shkola, 288 p. [in Russian].

8. Kolesnikova O. (2007). Frazeologizmyi so znacheniem emotsionalnogo sostoyaniya i ih rol v mezhkulturnoy kommunikatsii. [Phraseologisms with the meaning of an emotional state and their role in intercultural communication]. 
Uchenyie zapiski Tavricheskogo natsionalnogo universiteta im. V. I. Vernadskogo. Seriya «Filologiya». Vol. 20 (59). p.p. 319-324 [in Russian].

9. Kornieva Z. (2018). Onomastychnyi komponent u skladi anhliiskykh frazeolohichnykh odynyts ta yoho vidtvorennia v ukrainskomu perekladi. [Onomastic component in English phraseological units and its reproduction in Ukrainian translation ]. Molodyi vchenyi. № 11 (63). p.p. 321-326 [in Ukrainian].

10. Kunin A. V. (1970). O perevode angliyskih frazeologizmov. [About the translation of English phraseological units]. URL: http:// zhurnal.lib.ru/w/wagapow_a_s/transl/-bookkunin.shtml [in Russian].

11. Moroz O. (2011). Semantyka ta struktura nominatyvnykh frazeolohichnykh odynyts z komponentom «vlasne imia» [Semantics and structure of nominative phraseological units with the component "proper name"]. URL: http://nbuv.gov.ua/jpdf/Nchnpu_10_2011_8_77.pdf [in Ukrainian].

12. Motrichenko O. (2017). Kulturno-markovana leksyka suchasnoi movy hindi (typolohichnyi aspekt). [Culturally marked vocabulary of modern Hindi language (typological aspect)]. Indiia: davnyna $i$ suchasnist. Vol. II. p.p. 193-199 [in Ukrainian].

13. Muzya E. M. (2002). Printsipyi klassifitsirovaniya toponimov [Principles of classification of toponyms]. Visnyk Zaporizkoho derzhavnoho universytetu. Filolohichni nauky. № 1. p.p. 95-98 [in Ukrainian].

14. Pavlova T.N. (2011). Pragmaticheskiy potentsial kulturno-markirovannoy leksiki v publichnoy rechi. [The pragmatic potential of culturally-marked vocabulary in public speech]. Nova filolohiia. № 46. p.p. 174-176 [in Russian].

15. Selivanova O. (2012). Problema transformatsii v perekladoznavstvi. [The problem of transformations in translation studies]. Visnyk Cherkaskoho universytetu. Seriia filolohichni nauky. № 3. p.p. 33-40 [in Ukrainian].

16. Serebrennikov B. A. (1959). O metodah izucheniya toponimicheskih nazvaniy. [On the methods of studying toponymic names]. Voprosyi yazyikoznaniya. № 6. p.p. 36-51 [in Ukrainian].

17. Soloduho E. (1989). Teoriya frazeologicheskogo sblizheniya. [Theory of phraseological convergence ]. Kazan : KGU, 296 p. [in Russian].

18. Sudar G. S. (2004). Toponim v sostave ispanskogo frazeologizma. [Toponym in the Spanish phraseological unit]. Aktualnyie problemyi sovremennoy iberoromanistiki. Moskva : MGU. Fakultet inostrannyih yazyikov, p.p. 44 [in Russian].

19. Elliott K. (1996). A Survey of the History of English Place-Names. URL: heraldry.sca.org/names/engplnam.html

20. Mills A.D. (1991). A Dictionary of English Placenames. New York : Oxford University Press.

21. Szerszunowicz J. (2008). Some remarks on English idioms containing first names and their Polish equivalents. Proceedings. Nation and Language: Modern Aspects of Sociolinguistic Development. 2nd International Conference. Kaunas University of Technology, Panevėžys Institute. Lithuania. 